\title{
THE FIRST BULGARIAN STANDARDIZED SERIES FOR EPICUTANEOUS PATCH TESTING FOR ALLERGIES TO DENTAL MATERIALS AND ALLOYS
}

\author{
Maria Dencheva*, Iliana Stoeva**, Angelina Kisselova*, Assya Krasteva*, Bogdan \\ Petrunov***, George Nikolov***, Rumyana Hristova***, Yordan Galabov* \\ * Department "Oral and Image Diagnostics", Faculty of Dental Medicine - Sofia, \\ ** Department "Image diagnostics, physiotherapy and allergology", Faculty of \\ Dental Medicine - Plovdiv, \\ *** NCIPD - National Centre of Infectious and Parasitic Diseases, Bulgaria
}

\section{SUMMARY}

The teeth and teeth rows restoration in the maxillofacial area is the last stage of the ongoing patient treatment and a basic purpose for the dental doctors. For this purpose a different set of modern and classic contemporary dental materials is used. The choice of each material during the treatment of every patient with proven allergy to different kind of allergens is very specific and strictly individual. In the everyday oral diagnostics a standardized set of allergens for diagnostics is used for proving the allergy to dental materials. The set has been developed on the base of all existing and permitted by the Bulgarian authorities dental materials, as well as professional series.

The difference between the developed and standardized allergens for diagnostics used in our country and the existing ready-for-use series is that the first are made of the final product (material) in the form introduced to the oral cavity and persisting there for a different period of time, sometimes for tenths of years. This enables the possibility for early or late contact allergic reactions with symptoms in the oral cavity and on the skin, maxillofacial area, head and neck, as well as the entire organism.

The current article introduces the readers to the results obtained by the realization of the research project No.28/2011 "Research on the type of sensibilisation to contemporary dental materials and development of set of allergens for its diagnosing through epicutaneous patch testing" funded by the Committee of Medical science of MU Sofia (CMC). Through the project became possible the creation and the initial research of the first Bulgarian series for epicutaneous testing whose aim is to prove the allergenic potential of the most frequently used by the dental doctors dental materials.

Key words: Dental clinical allergology, Allergy to dental materials and dental alloys, Bulgarian allergenic materials for diagnostics.

\section{INTRODUCTION}

Thanks to a project funded by the CMC in 2011, a team of scientists from FDM Sofia and the National Centre of Infectious and Parasitic Diseases (NCIPD)- Acad. B. Petrunov Ph.D., Prof. A. Kisselova Ph.D., Doc. G. Nikolov Ph.D., Doc. Il. Stoeva Ph.D., D-r M. Dencheva Ph.D., D-r A. Krasteva Ph.D., R. Hristova, Ph.D., started development of set for epicutaneous testing to dental materials and alloys. The teeth and teeth rows restoration in the maxillofacial area is the last stage of the ongoing patient treatment and a basic purpose for the dental doctors. For this purpose a different kinds of classic and contemporary dental materials is used with components which have great irritative, allergenic and toxic potential $(2,6,11,12,19,23)$. Because of that, in the literature, very often an undesired reaction to dental materials is mentioned $(3,8,19,20,21)$. Despite the various mechanisms of arise and clinical symptoms of the side effects of the dental materials, the many years clinical experience and researches of Bulgarian and foreign authors shows that the allergic reactions are more frequent and are mostly IV kind reaction of hypersensitivity $(4,11,13,17,23)$. The epicutaneous testing is the only accessible in vivo method, through which an objective registration of the secondary reaction to dental materials could be made $(1,14,18,23)$.

The epicutaneous patch test is easy to do, requires standard allergens, relatively cheap and convenient for both the patient and the allergologist (10). The complexity at diagnosing the allergic reactions to dental materials comes from the scarce information for the exact components of the materials described in the sheets, as well as the lack of information for the exact mechanism the release of these components in the oral medium is made.

In the everyday oral and allergic diagnostics for proving of an allergy to dental materials, standard allergens for diagnostics are used, prepared from all dental materials permitted by the Bulgarian authorities, as well as professional serie. 
Usually a test with standard and screening series is made because during the anamnesis and clinical examination a definite allergen may be suspicious for causing the complains (22). Allergy diagnostics to dental materials in our country traditionally is made with allergens prepared by the trade product. The probe sample is pulverized and mixed with Vaseline in proportion 1:5 (9). A certain difficulty during the examination for sensibilisation to dental materials is the huge variety of trade products and the inability timely to be created allergen for diagnostics.

The choice of each material during the patient's treatment with diagnosed or presumed allergy to different kind of allergens is specific and strictly individual.

The aim of this study was to explore the sensibilisation potential of the contemporary dental materials used in our country and to create Bulgarian standard set of allergens based on the data received.

Assignments 96for completion of the given task:

1. Preparation of allergen products for epicutaneous patch testing to dental materials from the group of root canal sealers, composite restorative materials, adhesive systems, dental alloys, plastics and cements.

2. Conducting a comparison study of the allergic potential of the prepared allergens from dental materials and the ones from the standard dental series for patients, created on the basis of components in the dental materials, and to be compared with the allergic background of the examined patients $(\mathrm{n}=50)$.

3. Developing a Bulgarian standard set of allergens from dental materials in final form.

\section{MATERIALS AND METHODS}

1. Epicutaneous patch testing. The test is a part of skinallerigic trials. It is a provoking test on limited area of the skin with expected late reactions- slight erythema to typical exzema alterations. A test of choice are all dental materials included in the present project.

2. Intradermal and percutaneous skin-allergic tests from the standard series of allergens. At the intradermal skin test the allergen is directly injected in the most superficial layers of the skin. At percutaneous tests the allergen with the help of fine lancette is introduced under the epidermis. An early reaction is observed and recorded thanks to the IgEmediated immune mechanisms to the allergens from the standard series.

3. After receiving a data for positive skin-allergic tests, after the testing with standard series of allergens and anamnesis for simultaneous medicament allergy to antibiotics, the patients will be performed a quantity analysis of serum allergen-specific IgE antibodies by automated system ImmunoCAP.

\section{RESULTS:}

An inquiry amongst 50 dental doctors has been made, as each one of them has to point out the most used dental materials from different groups in his practice: alloys for metal-ceramic restorations, composite materials, root canal sealers, plastics and cements.

Based on the obtained results from this inquiry we choose 23 dental materials from different groups, which became a basis of the created Bulgarian series of allergens for diagnostics of allergic reactions with manifestation in the oral cavity and the whole organism (Table 1.).

Table 1. Dental materials, used for the creation of the Bulgarian allergen series for diagnostics.

\begin{tabular}{|c|c|c|c|c|}
\hline $\begin{array}{l}\text { Alloys for metal- } \\
\text { ceramic constructions }\end{array}$ & $\begin{array}{l}\text { Obturation } \\
\text { Materials }\end{array}$ & $\begin{array}{l}\text { Root canal sealing } \\
\text { materials }\end{array}$ & Plastics & Cements \\
\hline $\begin{array}{l}\text { Nickel-Chrome Alloys } \\
\text { 1. Crystalloy N } \\
\text { 2. Ugirex III } \\
\text { 3. I-Bond } 02 \\
\text { 4. Wiron } \\
\text { Cobalt- Chrome alloys } \\
\text { 5. Crystalloy M } \\
\text { 6. Ugirex C2 } \\
\text { 7. I-Bond NF } \\
\text { 8. Wiron } \\
\text { Nobel alloys(Au-Pd) } \\
\text { 9. Econady }\end{array}$ & $\begin{array}{l}\text { 1. Admira } \\
\text { 2. Gradia Direct } \\
\text { 3. Filtek Z } 250 \\
\text { 4. Valux Plus } \\
\text { 5. Grandioso } \\
\text { 6. Charisma }\end{array}$ & $\begin{array}{l}\text { Eugenol based materials } \\
\text { 1. Cortisomol } \\
\text { 2. Endomethasone } \\
\text { Based on epoxy resins } \\
\text { 3. AH-26 } \\
\text { 4. Adseal }\end{array}$ & $\begin{array}{l}\text { 1. Syperacryl } \\
\text { 2. Superpont } C+B\end{array}$ & $\begin{array}{l}\text { 1. Ketac } \\
\text { 2. Cegal } \\
\text { (phosphate } \\
\text { cement) }\end{array}$ \\
\hline
\end{tabular}


In the group of the dental alloys for metal-ceramic constructions were studied Nickel-Chrome, Cobalt-chrome and noble alloys (Au-Pd).

From the composite materials a group allergens for diagnostics were created by the products: Admira, Gradia Direct, Filtek Z 250, Valux Plus, Grandioso, Charisma.

Allergens were created by the root canal sealers on the basis of eugenol- Cortisomol, Endomethasone and on the basis of epoxy resins- AH-26, Adseal; from plasticsSuperacryl, Superpont C+B; cements- Ketac, Cegal (phosphate cement).

The data from the inquiry shows that:

- $72 \%$ of the inquired dental doctors collaborate with dental technicians who use Bulgarian alloys Crystalloy $\mathrm{M}$ and $\mathrm{N}$ for preparation of fixed constructions. Almost all dental technicians have in their lab, but use less frequently other alloys as - Ugirex-44\%, I-Bond-36\%, Wirbond-C-16\%,
Remanium 2000- 16\% and others.

- from the group of the composite materials the most frequently used are Filtek Z 250 (56\%), Valux Plus (52\%) and Gradia Direct (44\%), Charisma (34\%), Admira (34\%) and Grandioso (28\%). Less frequently used are Te-Econom $(14 \%)$, Premise (10\%), Tetric (4\%) and others.

- the most frequently used root-canal sealing paste is Cortisomol (82\%) followed by Endomethasone (64\%). Significant percentage of the the dental doctors uses sealers based on epoxy resins, required for the contemporary obturation techniques- AH-26 (42\%) and Adseal (34\%).

- the most frequently used plastics are Superacryl Plus (94\%) and Superpont C+B (92\%).

- in the variety rich group of cements, the classic phosphate cement remains, which is used by $96 \%$ of the dental doctors followed by Ketac- $76 \%$.

The obtained results are shown on Fig.1.
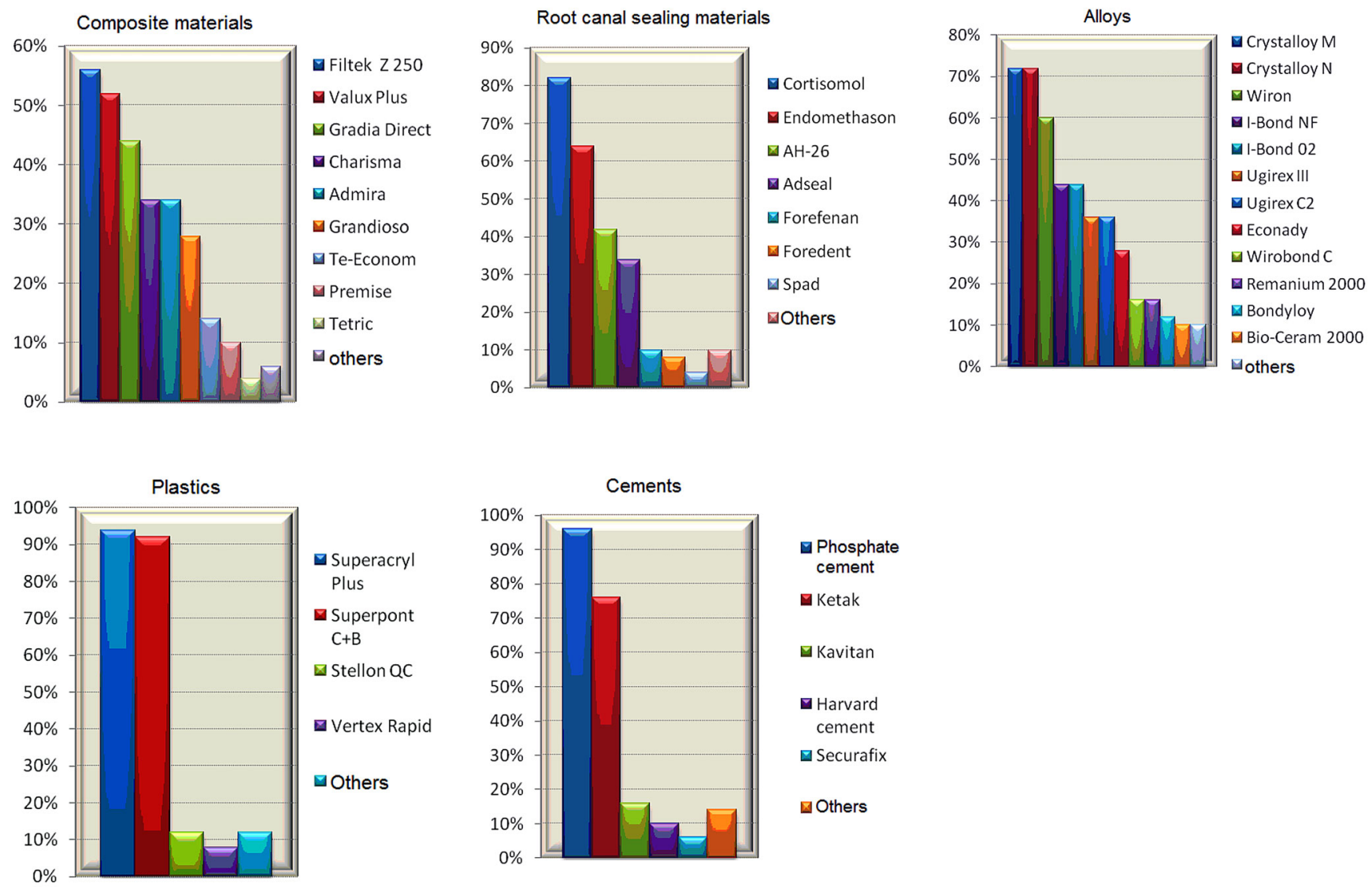

Fig.1 Results from the survey on the dental doctors for the most used dental materials .

On Figure 2 is shown the set of the Bulgarian allergens for diagnostics. 

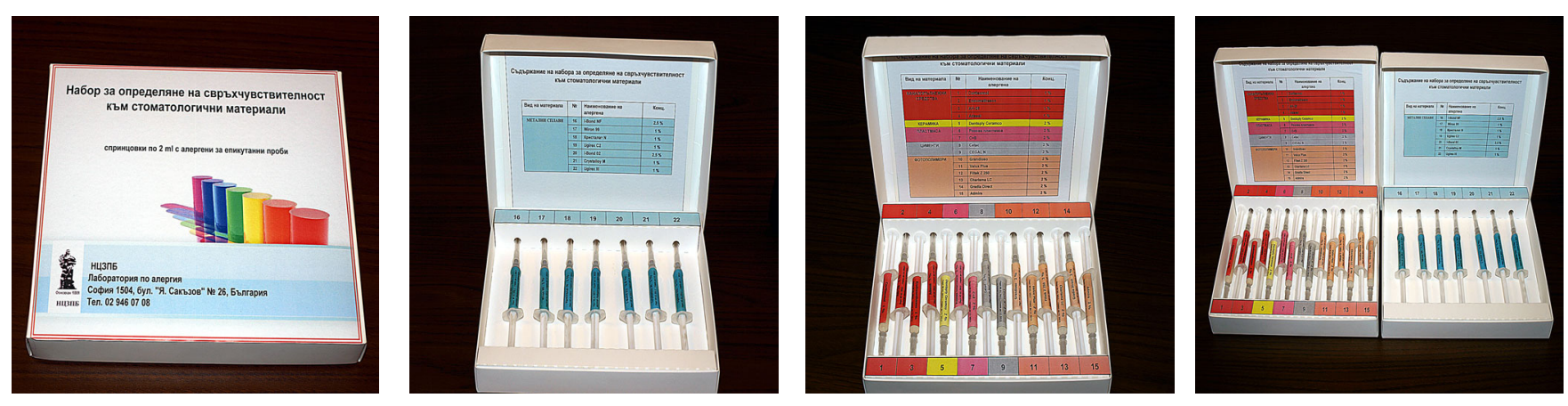

Fig. 2. Set of Bulgarian allergens for diagnostics of allergic reactions based on dental reconstruction materials

The clinical research of the prepared by us Bulgarian allergen series for diagnostics of allergic reactions on the basis of dental reconstruction materials was performed through epicutaneous patch testing on standardized methodic (Kisselova) on patients selected by us and corresponding to the criteria necessary to participate In the research. There were 43 patients with an average age of $22.49 \pm 1.14$ years, 23 men $(53,5 \%)$ and 20 women $(46,5 \%)$.

For this study we used hypoallergic plasters with polyethylene chambers of the Swedish company Chemotechnique Diagnostics (IQ Chambers ${ }^{\circledR}$, Vellinge, Sweden).

Skin-allergic tests we conducted through epicutaneous patch testing- classic methodics for diagnosing of contact allergy. The hypoallergenic plasters with the allergens stayed on the back for 48 hours. The registration of the tests we made few hours after the removal of the plasters and after the dissipation of the reflection erythema. The registration was made according to a scale approved by the International Contact Dermatitis Group (ICDRG):

+ slightly positive- pale erythema and oedema, possible single papules;

++ positive reaction- erythema, infiltrate, papules and single small vesicules;

+++ strongly positive reaction- well expressed erythema, infiltrate, numerous papules and vesicules, buli or generalized reaction;

IR- irraitative reaction- dissipates shortly after the plasters removal;

?- indeterminate- pale erythema

- negative reaction

A mandatory condition for the patients was to suspend any intake of antiallergic medicaments in the last week before the test.

\section{Alloys}

The greatest number of positive reactions were detected towards Cobalt-Chrome alloys, I-Bond NF, Crystalloy M and Ugirex C2, respectively $20.9 \%, 18.6 \%$, and $14 \%$, followed by the gold-palladium alloy Econady- $14 \%$.

Lowest allergic potential has the nickel-chrome alloy called I-Bond with $4.7 \%$ of the registered positive cases.

Table 2. Results obtained from the epicutaneous patch testing of dental materials.

\begin{tabular}{|l|c|c|c|c|c|}
\hline Alloy & Total & Indeterm. & Negative & Positive & \% \\
\hline Nickel-Chrome alloy & & & & & \\
\hline Crystalloy N & 43 & 0 & 38 & 5 & 11.6 \\
\hline Wiron & 43 & 0 & 40 & 3 & 7.0 \\
\hline Ugirex III & 43 & 0 & 38 & 5 & 11.6 \\
\hline I-Bond 02 & 43 & 0 & 41 & 2 & 4.7 \\
\hline Cobalt-Chrome alloy & & & & & 18.6 \\
\hline Crystalloy M & 43 & 0 & 35 & 8 & 14.0 \\
\hline Ugirex C2 & 43 & 0 & 37 & 6 & 20.9 \\
\hline I-Bond NF & 43 & 1 & 34 & 9 & 14.0 \\
\hline Gold- Palladium alloy & & & & & 6 \\
\hline Econady & 43 & 0 & 37 & & \\
\hline
\end{tabular}




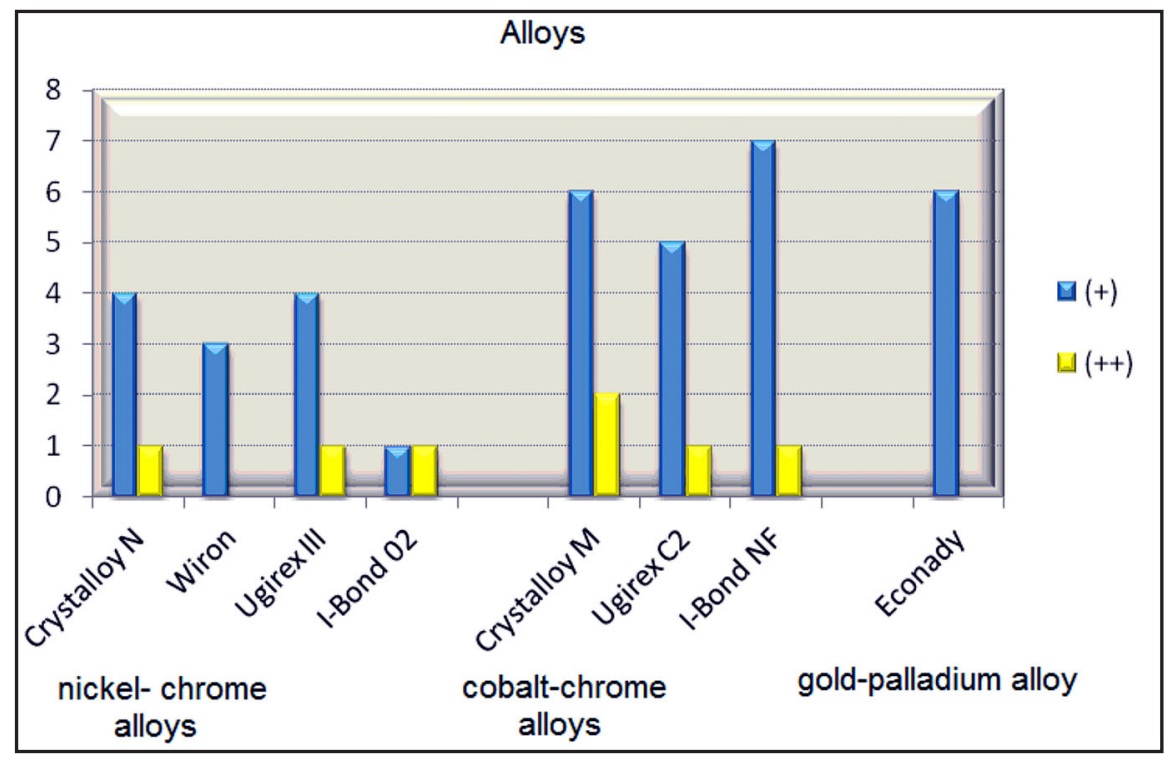

Fig. 3. Distribution of the positive reactions in exponents.

\section{Composite materials}

The greatest percentage of allergic reactions in the group of the composite materials was recorded towards Gradia Direct and Charisma- 9.3\%, and lowest to Valux- 2.3\% (table 3). All recorded reactions were slightly positive $(+$ ), with exception of the result of a patient who got positive reaction $(++)$ to the Charisma allergen (Fig. 4).

Table 3. Results from the epicutaneous patch testing to dental materials.

\begin{tabular}{|l|c|c|c|c|c|}
\hline Composite materials & Total & Indeterm. & Negative & Positive & \% \\
\hline Filtek & 43 & 0 & 41 & 2 & 4.7 \\
\hline Valux & 43 & 0 & 42 & 1 & 2.3 \\
\hline Admira & 43 & 0 & 41 & 2 & 4.7 \\
\hline Gradia Direct & 43 & 0 & 39 & 4 & 9.3 \\
\hline Charisma & 43 & 0 & 39 & 3 & 9.3 \\
\hline Grandioso & 43 & 0 & 40 & 3 & 7.0 \\
\hline
\end{tabular}

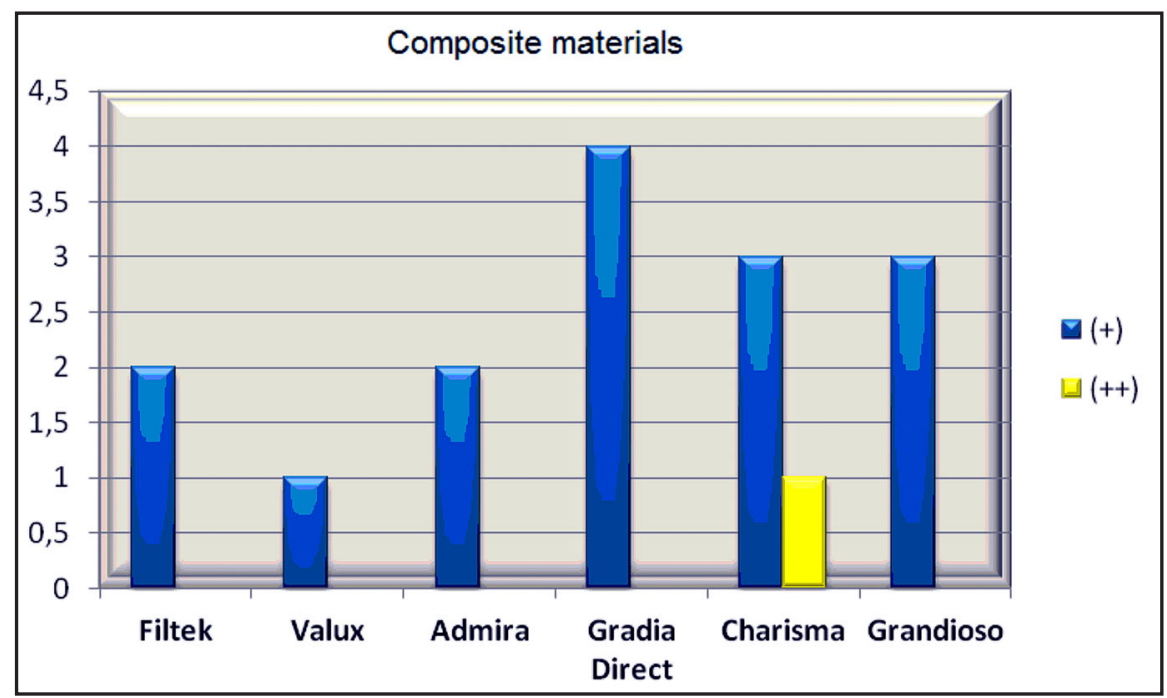

Fig. 4. Distribution of the positive reactions in exponents. 


\section{Root canal sealing pastes}

The greatest allergenic potential from this group belongs to Cortisomol- $25.6 \%$ (table 4 ). This is the allergen with the greatest count of positive reactions from the created set. The allergens prepared with pastes, based on epoxy resins, AH- 26 and Adseal also show significant amount of positive reactions, respectively at $7 \%$ and $9.3 \%$ of the examined patients. All patients who got positive reactions, were noted as slightly positive $(+)$ with an exception of a patient with positive reaction $(++)$ to Adseal (Fig. 5).

Table 4. Results from the epicutaneous patch testing to root canal sealing materials

\begin{tabular}{|l|c|c|c|c|c|}
\hline Root canal sealing pastes & Total & Indeterm. & Negative & Positive & \% \\
\hline Pastes with eugenol & & & & & \\
\hline Cortisomol & 43 & 1 & 31 & 11 & 25.6 \\
\hline Endomethasone & 43 & 0 & 39 & 4 & 9.3 \\
\hline Pastes containing epoxy resins & & & & & \\
\hline AH-26 & 43 & 0 & 40 & 3 & 7.0 \\
\hline Adseal & 43 & 0 & 39 & 4 & 9.3 \\
\hline
\end{tabular}

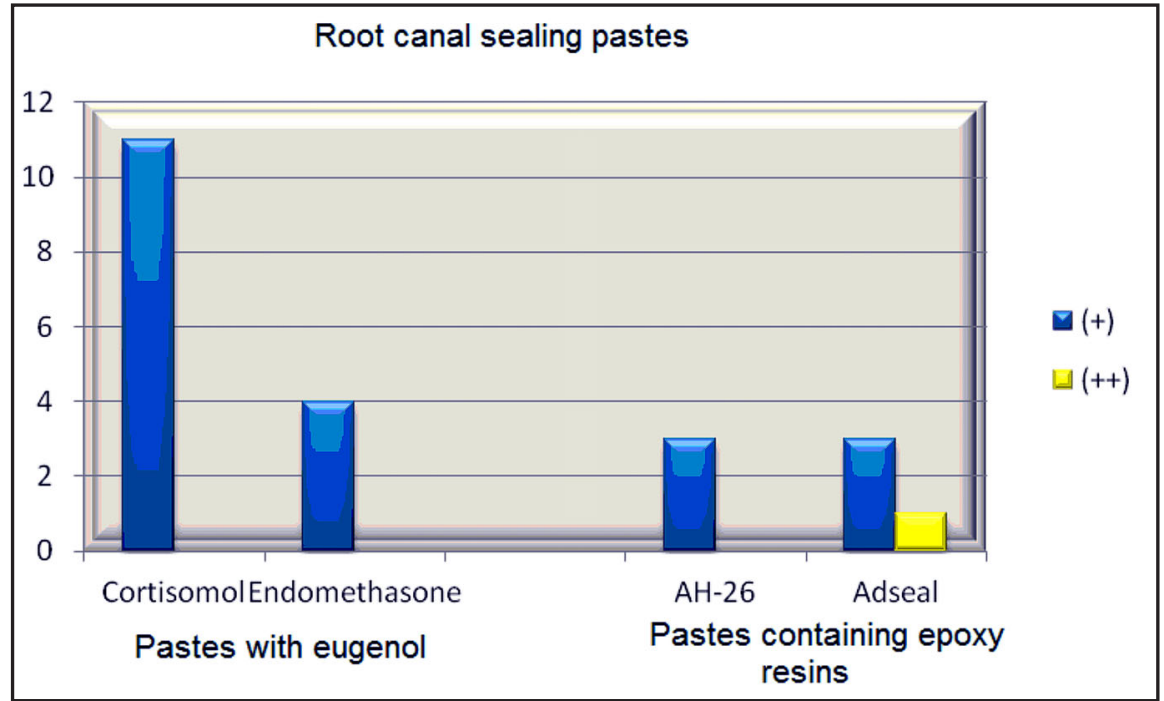

4. Plastics

Positive reactions to Superacryl Plus were detected at 5 patients $(11.6 \%)$ one of them with strong positive reaction $(+++)$.

Table 5. Results from the epicutaneous testing to dental plastics.

\begin{tabular}{|l|c|c|c|c|c|}
\hline Plastics & Total & Indeterm. & Negative & Positive & $\mathbf{\%}$ \\
\hline Superacryl Plus & 43 & 0 & 38 & 5 & 11.6 \\
\hline Superpont C+B & 43 & 0 & 39 & 4 & 9.3 \\
\hline
\end{tabular}

Fig. 5 Distribution of the positive reactions in exponents. 


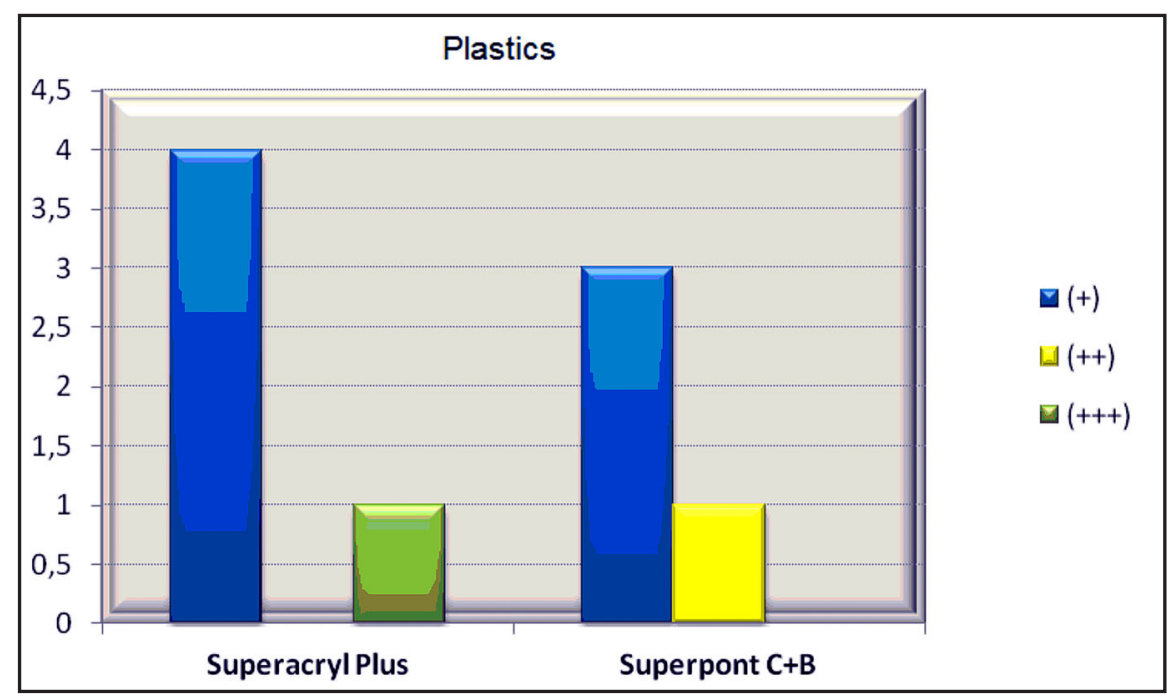

5. Cements

Table 6. Results from the epicutaneous tests to dental cements.

\begin{tabular}{|l|c|c|c|c|c|}
\hline Cements & Total & Indeterm. & Negative & Positive & $\mathbf{\%}$ \\
\hline Cegal & 43 & 0 & 38 & 5 & 11.6 \\
\hline Ketak & 43 & 0 & 38 & 5 & 11.6 \\
\hline
\end{tabular}

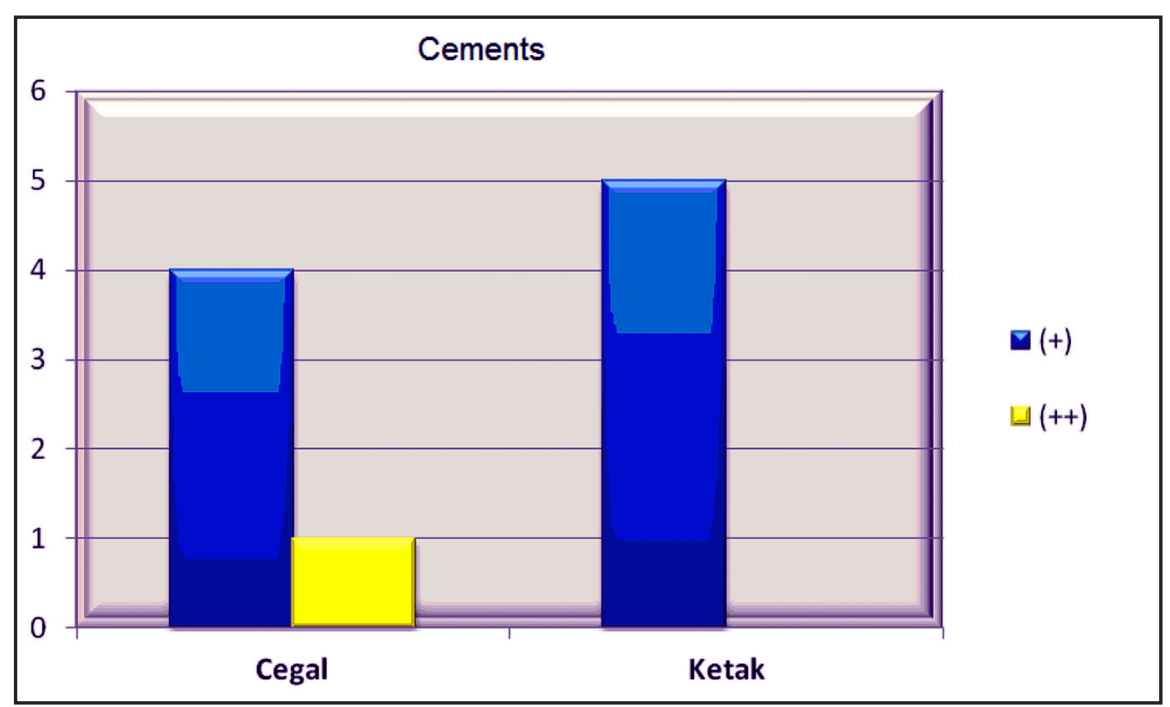

Fig. 6. Distribution of the positive reactions in exponents.
Fig. 7. Distribution of the positive reactions in exponents.

\section{DISCUSSION}

Traditionally the clinical testing of new materials in the medicine and particularly in the dental medicine is focused mainly on their physical and chemical properties. Controlled preclinical tests are made for few materials in limited amount of countries. In most countries allergy testing is not obligatory before a dental product is given a license for manufacturing (16). It is well known that the physical and mechanical properties of the dental materials differ from the starting products. In this meaning a difference could be expected in the sensitizing potential of the finished products, although their main components are known, as well as the allergic properties of each of them. Furthermore the manufacturer may not list some ingredients because of a company secret, which may also provoke a contact hypersensitivity $(5,7)$.

Some authors publish an interesting articles about a significant difference between the listed ingredients in the prospects of the dental materials, and the data received from the chromatographic analysis on samples of these materials 
$(5,7)$. The authors find that in the catalog of some products are declared only half of the used components, which hides a potential risk for the patient's health and the health of the dental-medicine staff, in the cases when a certain ingredients must be avoided.

This fact gives the authors a reason to do epicutaneous patch testing with the ready-to-use products on some patients.

In perspective a more detailed research and additions to the Bulgarian series of dental materials are possible and necessary. This more specific action could be realized by the started by this team comparison study on the sensitization to dental materials from the series of finished products to the sensitization to allergens as separate components of the dental materials.

\section{CONCLUSION}

The diagnose contact allergy to dental materials is hard and responsible process. In order to do a definitive diagnose one a mandatory condition is the usage of standardized allergens.

The newly created Bulgarian series of allergens, for diagnosing of allergic reactions based on dental restorative materials, by leading Bulgarian scientists in the domain of the clinic allergology and immunology is a significant contribution in the Bulgarian medical science and has an essential meaning for the everyday practice, for the oral diagnostics as well as the clinical practice of the dental doctors.

\section{REFERENCES:}

1. De Rossi SS, Greenberg MS. Intraoral contact allergy: A literature review and case reports. J Am Dent Assoc. 1998 Oct;129(10):1435-1441. [PubMed]

2. Djerasi E, Petrunov B. Alergologichni problem $\mathrm{V}$ stomatologiata. Medizina I phizkultura, Sofia, 1990, 245 p. [in Bulgarian]

3. Gawkrodger DJ. Investigation of reactions to dental materials. Br J Dermatol. 2005 Sep;153(3):479-485. [PubMed] [CrossRef]

4. Geurtsen W. Biocompatibility of dental casting alloys. Crit Rev Oral Biol Med. 2002; 13(1):71-84. [PubMed] [CrossRef]

5. Henriks-Eckerman ML, Suuronen K, Jolanki R, Alanko K. Methacrylates in dental restorative materials. Contact Dermatitis. 2004 Apr;50(4):233-237. [PubMed] [CrossRef]

6. Ivanova, I. Intraoralna kontaktna svruhchuvstvitelnost kam zaboprotezni materiali. Dis. FDM Sofia, 2008, 173p. [in Bulgarian]

7. Kanerva L, Henriks-Eckerman ML, Jolanki R, Estlander T. Plastics/Acrylics: Material Safety data sheets need to be improved. Clin Dermatol. 1997 JulAug;15(4):533-546. [PubMed] [CrossRef]

8. Kisselova-Yaneva, A. Reactions to materials used in dentistry. Godishen sbornik IMAB, 2001, 7(2):135-136.
9. Kisselova-Yaneva A. Stomatogenni poleta na smustenie pri njakoi hronichni zaboljavania i alergii. Dok. dis, Stom. Fac, Sofia, 2000,371p. [in Bulgarian]

10. Kisselova-Yaneva A. Stomatologichna alergologia i ognistna diagnostika. monographia, IK “Gutenberg”, Sofia, 2001, $327 \mathrm{p}$. [in Bulgarian]

11. Kisselova-Yaneva A. Ognistno deistvasti factori $\mathrm{v}$ zabno-chelustnata sistema pri deza I iunoshi na teritoriata na grad Ruse. Dis. Stom fac Sofia, 1981,169 p.(3) [in Bulgarian]

12. Leggat PA, Kedjarune U. Toxicity of methylmethacrylate in dentistry. Int Dent J. 2003 Jun;53(3): 126-131. [PubMed]

13. Lygre GB, Gjerdet NR, Gronningsaeter AG, Bjorkman L. Reporting on adverse reactions to dental materials intraoral observations at a clinical followup. Community Dent Oral Epidemiol. 2003 Jun;31(3):200-206. [PubMed] [CrossRef]

14. Lygre H. Prosthodontic biomaterials and adverse reactions: a critical review of the clinical and research literature. Acta Odontol Scand. 2002 Jan;60(1):1-9. [PubMed]

15. Mallo-Perez L, Diaz-Donado C. Intraoral contact allergy to materials used in dental practice. A critical review. Med Oral. 2003 Nov-Dec;8(5):334-47. [PubMed]

16. Mjor IA. Biological side effects to materials used in dentistry. $J R$ Coll Surg

\section{Corresponding author:}

Dr. Maria Dencheva-Garova, PhD.

Department of Image and Oral diagnostic,

Faculty of Dental Medicine, Medical University - Sofia.

1, Sv. George Sofiiski boul., 1431 Sofia, Bulgaria

Mob.: +359/889 317316

e-mail: jivena@abv.bg
Edinb. 1999 Jun;44(3):146-149. [PubMed]

17. Mjor IA. Side effects of dental materials. BMJ. 1994 Sep 10; 309 (6955):621-622. [PubMed] [CrossRef]

18. O'Connor WJ, Rogers RS, Sheridan PJ, Reeve CM. Allergic contact stomatitis, a 20 year experience. J Eur Acad Dermatol Venereol. 1997, 9 (Suppl.1):163-163.

19. Petrunov B, Djerasi E, Stanoeva E. Promjana na imunologichnata reaktivnost na stomatolosi pod vlijanie na profesionalnite alergizirasti factori. Stomatologia. 1977, VIX, 6, 397-401. [in Bulgarian]

20. Scott A, Egner W, Grawkrodger DJ, Hatton PV, Sherriff M, van Noort R, et al. The national survey of adverse reactions to dental materials in the UK: a preliminary study by the UK Adverse Reactions Reporting Project. Brit Dent J. 2004 Apr;196(8):471-477. [PubMed] [CrossRef]

21. Tosic, G. Occupational hazards in dentistry - part one: allergic reactions to dental restorative materials and latex sensitivity. Facta Universitatis, Series: Working and Living Environmental Protection 2004; 2 (4):317-324.

22. van der Valk PG, Devos SA, Coenraads PJ. Evidence-based diagnosis in patch testing. Contact Dermatitis. 2003 Mar;48(3):121-125. [PubMed] [CrossRef]

23. Wataha JC. Biocompatibility of dental casting alloys: A review. J Prosthet Dent. 2000 Feb;83(2):223-234. [PubMed] 